Reprod. Nutr. Dévelop., 1987, 27 (2 B), 581-589.

\title{
Biotechnology in the potential practical application of somatotrophic hormones for improving animal performance
}

\author{
G. S. G. SPENCER (1)
}

\author{
Ciba-Geigy S.A., Biovet Unit, Centre \\ de Recherches Agricoles, \\ St-Aubin (FR), CH-1566, Switzerland.
}

Summary. The use of biotechnology now allows adequate supplies of previously scarce substances. This has enabled evaluation of some of these substances as enhancers of animal performance. Growth hormone $(\mathrm{GH})$ shows promise as a stimulator of lactation in a number of species, but its effects on the stimulation of growth are somewhat equivocal. Somatocrinin, by virtue of its $\mathrm{GH}$ - releasing activity, may also be potentially useful, though to date the effects of somatocrinin administration have been less promising than those for $\mathrm{GH}$ directly. Somatomedin (IGF-1), as the active mediator of $\mathrm{GH}$, might be expected to be useful in growth promotion but, as yet, it has not been convincingly demonstrated to stimulate growth in normal animals. All these hormones have the major drawback that, until a suitable slow-release/delivery mechanism is available, they need to be administered very frequently. An alternative approach, immuno-neutralization of the growth inhibiting effects of somatostatin, has been demonstrated to enhance growth; although at present still requiring multiple treatments such a technique potentially has many advantages.

\section{Introduction.}

Recent developments in our understanding of neuro-endocrine and hormonal factors involved in growth, together with rapid advances in biotechnology, have produced an environment for potentially exciting changes in our ability to regulate animal performance. For example, recombinant DNA technology has made possible the large scale production of metabolic hormones that were previously available only in small quantities. Such use of biotechnology is, however, just one of the steps that need to be taken if the somatotrophic hormones are to be used as a means of improving animal performance. One of the first requirements is to show that the hormones can actually have a beneficial effect ; for the most part, such data are not still available.

The principal somatotrophic hormones are : somatotropin (growth hormone, $\mathrm{GH}$ ), somatomedin-C (insulin-like growth factor 1, IGF-1), somatocrinin (GH releasing factor, GRF) and somatostatin (GH release inhibiting factor, SRIF). The major potential applications for the somatotrophic hormones are in growth and lactation, however the hormonal control of these phenomena relies upon a com-

(1) Present address : c/o Institute of Food Research, Langford, Bristol, Great Britain. 
plex interaction between many different hormones (Spencer, 1985). Thus, although these hormones are the central factors involved in growth and lactation, simple application of a single hormone may not be sufficient to enhance productivity.

The following discussion will review the available data to support a practical application for each of these hormones in the stimulation of growth and lactation and assess the potential of each at present.

\section{Lactation}

\section{Growth hormone}

It appears that $\mathrm{GH}$ plays two distinct, yet contradictory roles. It has a positive effect in stimulating growth (most, if not all, of which is believed to be mediated by IGF-1) and a potent catabolic effect as demonstrated by its ability to breakdown fats (Jagannadha and Ramachandran, 1977).

It is well known that administration of exogenous growth hormone during established lactation increases milk yield. Consistent positive effects, with increases of between 10 and $40 \%$ in milk yield, have been observed with $\mathrm{GH}$ administration to cows during mid- or late-lactation, but the effect on milk production in early lactation is equivocal (Bines and Hart, 1982 ; Brumby and Hancok, 1955). This galactopoietic effect has been demonstrated in not only in cattle $(e . g$. Peel et al., 1983), but also in sheep (Jordan and Schaffhausen, 1954), goats (Mepham et al., 1984) and pigs (Harkins et al., 1985).

The precise mechanisms by which $\mathrm{GH}$ stimulates milk production are unknown. The catabolic effects of $\mathrm{GH}$ are likely to be important in providing at least part of the energy required and it appears that the improvement in milk yield is due to increased utilization of body tissues for milk production (Peel et al., 1982). It also seems possible, however, that increased IGF-1 production following $\mathrm{GH}$ treatment in lactation (Peel et al., 1985) may have effects on the mammary gland (Baumrucker, 1986).

There is neither an apparent increase in digestibility (Peel et al., 1982 ; Tyrrell et al., 1982) nor a change in partial efficiency of milk synthesis (Tyrrell et al., 1982) when lactating cattle are treated with $\mathrm{GH}$, but the increase in milk vield is associated with a marked increase in voluntary food intake within a few weeks of the start of treatment (Bauman et al., 1985). Depending upon the feeding regime and production response, it has been estimated that this increase in intake may result in up to a $110 \%$ increase in concentrate requirements (Kalter et al., 1985), however it may still remain a viable approach to increasing overall milk production efficiency.

Perhaps the major unresolved variables are : whether there is any detrimental effect of such alteration of maternal metabolism on the viability and subsequent performance of the calf; whether or not there is a prolonged increase in food intake during the re-feeding period; and what is the effect of such treatment upon subsequent lactational performance. In addition to this there is also the 
major practical disadvantage that currently there is no effective long-term, or slow-release mechanism for such peptides which seems suitable for practical use.

\section{Somatocrinin}

With the isolation and characterization of GRF, attention has recently been paid to the use of GRF to stimulate endogenous $\mathrm{GH}$ release in dairy cattle. In short-term experiments, human pancreatic GRF administered to mid- to latelactation cows stimulated an $11 \%$ increase in milk yield (Enright et al., 1986). Although the results look promising, there are some reservations. On the practical side, the same problems of administration are present with GRF as with $\mathrm{GH}$. On the physiological side, it has been shown that long-term administration of GRF depletes pituitary GH stores (Wehrenberg et al., 1984 ; von Werder et al., 1984). Furthermore, there may be receptor down-regulation as occurs with repeated LHRH administration. Thus the long-term use of GRF during lactation may be precluded.

\section{IGF-1}

It has been postulated that IGF-1 may modulate some of the galactopoietic effects of $\mathrm{GH}$ at the level of the mammary gland, but so far direct data are lacking. The recent production of IGF-1 from bacterial sources now offers the opportunity for such studies. The finding of IGF-1 receptors in mammary tissue, the changes in these receptors during pregnancy and lactation (Campbell and Baumrucker, 1986) and the stimulation of milk production by IGF-1 in vitro (Baumrucker, 1986) lend support to the possible use of IGF-1 as a stimulator of milk yield.

\section{Somatostatin}

Somatostatin, by inhibiting $\mathrm{GH}$ release, would be expected to reduce milk yield ; removal of the SRIF, on the other hand, elevates GH levels (Ferland et al., 1976) and might be expected to increase milk yields. There is only one published report on the effects of immuno-neutralization of SRIF on milk yield. In a preliminary study with goats it was found that immuno-neutralization of somatostatin during pregnancy resulted in increased milk production up until the time of peak lactation, thereafter there was no difference between treated and control animals (Spencer, Garssen and Welling, 1985). This preliminary observations needs to be confirmed, but such immuno-neutralization, or use of an antagonist to SRIF (Spencer and Hallett, 1985) could provide an alternative approach to the use of $\mathrm{GH}$.

\section{Growth}

\section{Growth hormone}

The relative roles of various hormones in regulating growth have recently been reviewed (Spencer, 1985). Although $\mathrm{GH}$ is a central factor in regulating growth, there is little correlation between circulating $\mathrm{GH}$ levels and growth rate in 
normal animals. The reason for this seems to be due to the complex interactions between $\mathrm{GH}$ and other hormones that is required for growth (Spencer, 1985). Thus, although $\mathrm{GH}$ is essential for growth, and restores growth in hypopituitary or hypophysectomized animals, its effects on stimulating growth rates in normal farm animal species is far from consistent; even consecutive studies from the same laboratory produce conflicting results (Wolfram, Ivy and Baldwin, 1985). Some of the problems associated with this variability in response $(e . g$. use of heterologous $\mathrm{GH}$, purity, dose) have recently been discussed by Chung, Etherton and Wiggins (1985).

Some of the studies attempting to stimulate growth using $\mathrm{GH}$ are shown in Table 1. Machlin (1972) and Chung, Etherton and Wiggins (1985) have reported stimulation of growth in swine using porcine $\mathrm{GH}$. In sheep, Wagner and Veenhuizen (1978) found stimulation of growth with $\mathrm{GH}$ administration, while Wheatley et al. (1966) and Muir et al. (1983) were unable to get a positive effect. In poultry, Leung et al. (1986) have reported a slight positive effect during the first week of treatment, but no significant effect during the later stages. On the positive side, an almost universal finding in these studies is an improvement in food conversion efficiency and a decrease in the amount of carcass fat, even when there is no effect on growth rate.

\section{TABLE 1}

Some studies on the use of $\mathrm{GH}$ to stimulate growth in normal farm animals $(+$ : positive effect on growth ; - : no effect on growth).

\begin{tabular}{|c|c|c|c|}
\hline First author & Date & Species & Growth \\
\hline Brumby ...... & 1959 & Heifer & + \\
\hline Wheatley et al. ................. & 1966 & Sheep & - \\
\hline Machlin ......... & 1972 & Pig & + \\
\hline Wagner et al. .. & 1978 & Sheep & + \\
\hline Muir et al. $\ldots \ldots \ldots \ldots \ldots \ldots$ & 1983 & Sheep & - \\
\hline Chung et al. $\ldots \ldots \ldots \ldots \ldots \ldots$ & 1985 & Pig & + \\
\hline Leung et al. . . . . . . . . . . . . & 1986 & Chicken & $+1-$ \\
\hline
\end{tabular}

To summarize, the effects of $\mathrm{GH}$ administration are, as yet, not reliable enough to consider its use in practice ; probably because administration of exogenous hormones ignores (and upsets) the sensitive interrelationship between various hormones and ignores the possible effect of elevation of plasma levels on receptor populations.

Thus, although biotechnology has brought the ability to make pure preparations of growth hormones in large quantities, it has not yet produced the wherewithal to provide a long-term, or slow-release, mechanism for administration.

\section{Somatocrinin}

The isolation and chemical characterization of GRF has now enabled evaluation of this substance as a growth promoter. The studies undertaken so far have not suggested that this is a useful way of stimulating growth rate. Immunoneutralization of GRF is a potent inhibitor of growth (Wehrenberg, Bloch and Phillips, 
1984), but in chickens (Baile, Della-Fera and Buonomo, 1985 ; Leung et al., 1986) and in swine (Etherton et al., 1985) administration of exogenous GRF has no significant effect on growth. Possibly this may be due to inappropriate dosage or route of administration, but the effect of continued GRF in exhausting releasable GH from the pituitary may also be a factor (Wehrenber et al., 1984 ; Baile, DellaFera and Buonomo, 1985).

\section{IGF-1}

As with GRF, the availability of large quantities of IGF-1 is only now allowing studies on the effects of IGF-1 in normal animals. IGF-1 has been shown to partially restore growth in hypophysectomized (Schoenle et al., 1982) and hypopituitary (van Buul-Offers and Van den Brande, 1979) animals, but published data on the effects in normal animals are lacking; unpublished data, however, suggest that exogenous IGF-1 has no effect on total body growth. As with GH and GRF, there is no suitable vehicle available for long-term administration, thus whatever the effects of IGF-1 on growth in farm animal species, its use is at present restricted.

\section{Somatostatin}

As an alternative to increasing the levels of growth stimulating hormones it may prove equally, or even more, effective to remove endogenous growth inhibitors. Perhaps the major inhibitor of total somatic growth is SRIF. As well as inhibiting the release of $\mathrm{GH}$, it also inhibits the release of insulin, thyroid hormones and many gastro-intestinal hormones, thereby affecting both the ability of the animal to absorb nutrients and its subsequent ability to direct these nutrients into tissue growth.

The use of a somatostatin antagonist has been found to stimulate growth in rats (Spencer and Hallett, 1985), but this kind of treatment also suffers from the drawbacks of GH, IGF-1 and GRF in that it requires daily injections. A possible practical alternative is the use of immuno-neutralization. To date, passive immunization of SRIF (administration of antibodies into the animal) has not been found

\section{TABLE 2}

Some studies on the use of immunization against somatostatin to promote growth. Growth as percent of controls

\begin{tabular}{|c|c|c|c|}
\hline First author & Date & Species & Growth \\
\hline 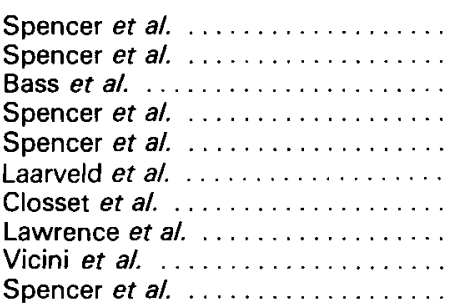 & $\begin{array}{l}1981 \\
1983 \\
1983 \\
1984 \\
1985 \\
1986 \\
1986 \\
1986 \\
1986 \\
1986\end{array}$ & $\begin{array}{l}\text { sheep } \\
\text { sheep } \\
\text { sheep } \\
\text { pig } \\
\text { sheep } \\
\text { sheep } \\
\text { cattle } \\
\text { cattle } \\
\text { cattle } \\
\text { chicken }\end{array}$ & $\begin{array}{l}176 \% \\
125 \% \\
110 \% \\
118 \% \\
109 \% \\
117 \% \\
111 \% \\
118 \% \\
109 \% \\
115 \%\end{array}$ \\
\hline
\end{tabular}


to have any growth stimulating effect (Spencer et al., 1986), but active immunization appears to be a powerful, safe, effective tool to enhance growth (for a review see Spencer, 1986).

In a preliminary study using twin St Kilda lambs, active immunization against SRIF resulted in the treated lambs growing at $176 \%$ of the rate of the control lambs (Spencer and Williamson, 1981). Subsequent studies have been unable to reproduce this figure, but an improvement of $15-20 \%$ in growth rate is more usual (Table 2). The somatostatin-14 molecule is the same in all farm animal species, and it has now been shown that active immunization against SRIF can stimulate growth in commercially important breeds of sheep (Spencer, Hallett, and Fadlalla, 1985 ; Laarveld et al., 1986), cattle (Closset et al., 1986 ; Lawrence et al., 1986), pigs (Spencer, 1984 ; Laarveld, personal communication) and chickens (Spencer et al., 1986).

As well as stimulating growth rate and leading to a $20 \%$ reduction in rearing time (Spencer, 1984), active immunization against SRIF also has a beneficial effect on food conversion efficiency. In addition to the saving on food by virtue of more rapid growth, the animals actually utilise their food more efficiently during the growing period (Spencer, Garssen and Bergström, 1983), at least partly as a result of changes in gut motility (Fadlalla, Spencer and Lister, 1985 ; Faichney and Barry, 1985). The treatment does not have any marked affect on carcass composition (Spencer, Garssen and Bergstrom, 1983) but there are indications that, when killed at equal weights, treated animals may be leaner, perhaps by virtue of being youger (unpublished observations).

There are numerous advantages to the use of immuno-neutralization against SRIF as a means of growth promotion : since SRIF regulates the release of many interrelated hormones, the treatment does not affect a single hormone, but a whole endocrine system ; it is also essentially free from residues since the antibodies remove all administered materials ; and, being fairly long-term in its effects, it does not require continuous treatment. The disadvantage is that the results are variable due to differences in immune response between animals. A better understanding of the workings of the immune system should help alleviate this problem.

12e Réunion du groupe Développement INRA Montpellier, 28-30 mai 1986.

Résumé. Possibilités offertes par la biotechnologie dans l'amélioration des performances animales par les hormones somatotropes.

La biotechnologie permet aujourd'hui d'obtenir en quantité convenable des substances autrefois très rares. Ceci a rendu possible l'appréciation de l'aptitude de ces substances à augmenter les performances des animaux d'élevage. L'hormone somatotrope (GH) stimule la lactation dans plusieurs espèces, mais ses effets sur la croissance sont ambigüs. La somatocrinine, par le biais de son action sur l'excrétion de la $\mathrm{GH}$, peut également être utile, quoique ses effets soient moins prometteurs que ceux de la GH. La somatomédine (IGF-1), médiateur de la $\mathrm{GH}$, devrait stimuler la croissance, mais chez l'animal normal son action ne s'est pas montrée convaincante. Toutes ces hormones présentent le même inconvénient : tant qu'un procédé ne permettra pas leur libération progressive dans l'organisme, leur administration devra être répétée à intervalles rapprochés. Une autre éventualité serait la neutralisation, par des anticorps, de la somatostatine, substance inhibitrice de la croissance. Bien qu'elle nécessite également des interventions multiples, cette technique présente de nombreux avantages. 


\section{Références}

BAILE C. A., DELLA-FERA M. A., BUONOMO C., 1985, Long-term treatment of cows, sheep and chickens with GRF : effects on lasma GH level and on growth and production, 359-370. In A. JOYEAUX, G. LEYGUE, M. MORRE, R. RONCUCCI, P. M. SCHMELCK, Therapeutic agents produced by genetic engineering: quo vadis? Sanofi Research. Montpellier.

BASS J. M., GLUCKMAN P. D., FAIRCLOUGH R. J., PETERSON A. J., DAVIS S. R., 1983. Effect of immunisation against somatostatin and feed quality on growth controlling hormones and body composition. Proc. Endocr. Soc. Austr. August (Abstr.)

BAUMAN D. E., McCUTCHEON S. N., STEINHOUR W. D., EPPARD P. J., SECHEN S. J., 1985. Sources of variation and prospects for improvement of productive efficiency in the dairy cow: a review. J. anim. Sci., 60, 583-592.

BAUMRUCKER C. R., 1986. Insulin-like growth factor-1 (IGF-1) and insulin stimulates lactating bovine mammary tissue DNA synthesis and milk production in vitro. J. Dairy Sci., 69, Suppl. 1, p. 120.

BINES J. A., HART I. C., 1982. Metabolic limits to milk production, especially roles of growth hormone and insulin. J. Dairy Sci., 65, 1375-1389.

BRUMBY P. J., 1959. The influence of growth hormone on growth in young cattle. N. Z. J. agric. Res., 2, 683-689.

BRUMBY P. J., HANCOCK J., 1955. The galactopoietic role of growth hormone in dairy cattle. N. Z. J. Sci. Tech., A 36, 417-436.

CAMPBELL P. G., BAUMRUCKER C. R., 1986. Characterization of insulin-like growth factor-1/ somatomedin-C receptors in the bovine mammary gland. J. Dairy Sci., 69, Suppl. 1. Abstract P218G.

CHUNG C. S., ETHERTON T. D., WIGGINS J. P., 1985. Stimulation of swine growth by porcine growth hormone. J. anim. Sci., 60, 118-130.

CLOSSET J., MAGHUIN-ROGISTER G., TRAN QUANG MINH, LAMBOT O., HENNEN G., 1986. Growth promotion in bulls using a synthetic vaccine against somatostatin. Proc. 12e Reun. Groupe Développement, INRA, 28-30 May, Montpellier.

ENRIGHT W. J., CHAPIN L. T., MOSELEY W. M., ZINN S. A., TUCKER H. A., 1986. Growth hormone releasing factor stimulates milk production and sustains growth hormone release in Holstein cows. J. Dairy Sci, 69, 344-351.

ETHERTON T. D., WIGGINS J. P., CHUNG C. S., REBHUN J. F., WALTON P. E., 1985. Anabolic effects of long-term administration of growth hormone-releasing factor (GRF) and growth hormone on swine. Proc. Endocr. Soc. Abstr. 475.

FADLALLA A. M., SPENCER G. S. G., LISTER D., 1985. The effect of passive immunization against somatostatin on marker retention time in lambs. J. anim. Sci, 61, 234-239.

FAICHNEY G. J., BARRY T. N., 1985. Intravenous somatostatin infusion affects gastro-intestinal function in sheep. Can. J. anim. Sci., 64 (suppl.) 93-94.

FERLAND L., LABRIE F., JOBIN M., ARIMURA A., SCHALLY A. V., 1976. Physiological role of somatostatin in the control of growth hormone and thyrotropin secretion. Biochem. biophys. Res. Commn., 68, 149-155.

HARKINS M., BOYD R. D., BAUMAN D. E., BUTLER W. R., 1985. Effect of recombinant porcine growth hormone on milk production and sow and litter performance. J. anim. Sci, 61. Suppl. 1. 316.

JAGANNADHA A., RAMACHANDRAN J., 1977. In C. H. LI. Hormonal proteins and peptides, Acad. Press, New York, San Francisco and London, p. 43.

JORDAN R. M., SCHAFFHAUSEN D. D., 1954. Effect of somatotropin on milk yield of ewes. J. anim. Sci., 13, 706-710.

KALTER R. J., MILLIGAN R., LESSER W., MAGRATH W., TAUER L., BAUMAN D. E., 1985. Biotechnology and the dairy industry: production costs, commercial potential and economic impact of the bovine growth hormone. Publ. no. A. E. Res 85-20. Cornell Univ., U.S.A. 1123.

LAARVELD B., CHAPLIN R. K., KERR D. E., 1986. Somatostatin immunization and growth in lambs. Can J. anim. Sci., 66, 77-83. 
LAWRENCE M. E., SCHELLING G. T., BYERS F. M., GREENE L. W., 1986. Improvement of growth and feed efficiency in catlle by active immunization against somatostatin. J. anim. Sci., 63, Suppl. 1. 215.

LEUNG F. C., TAYLOR J. E., WIEN S., VAN INDERSTINE A., 1986. Purified chicken growth hormone $(\mathrm{GH})$ and a human pancreatic $\mathrm{GH}$-releasing hormone increase body weight gain in chickens. Endocrinology, 118, 1961-1965.

MACHLIN L. J., 1972. Effects of porcine growth hormone on growth and carcass composition of the pig. J. anim. Sci, 35, 794-800.

MEPHAM T. B., LAWRENCE S. E., PETERS A. R., HART I. C., 1984. Effects of exogenous growth hormone on mammary function in lactating goats. Horm. Metab. Res., 16. 248-253.

MUIR L. A., WIEN S., DUQUETTE P. F., RICKES E. L., CORDES E. H., 1983. The effects of exogenous growth hormone and diethylstilbestrol on growth and carcass composition of growing lambs. J. anim. Sci, 56, 1315.

PEEL C. J., FRONK T. J., BAUMAN D. E., GOREWIT R. C., 1983 . Effect of exogenous growth hormone in early and late lactation on lactational performance of dairy cows. J. Dairy Sci, 66, 776.782 .

PEEL C. J., SANDLES L. D., QUELCH K. J., HERINGTON A. C., 1985. The effects of long-term administration of bovine growth hormone on the lactational performance of identical-twin dairy cows. Anim. Prod., 41, 135-142.

PEEL C. J., STEINHOUR W. D., BAUMAN D. E., TYRRELL H. F., BROWN A. C. G., REYNOLDS P. J., HAALAND G. L., 1982. Administration of bovine growth hormone to high yielding Holstein cows. II. Influence on irreversible loss and oxidation rate of free fatty acids and glucose. J. Dairy Sci, 65, Suppl. 1. 120-121.

SCHOENLE E., ZAPF J., HUMBEL R. E., FROESCH E. R., 1982. Insulin-like growth factor-1 stimulates growth in hypophysectomized rats. Nature, 296, 252-253.

SPENCER G. S. G., 1984. Effect of immunization against somatostatin on growth rate of lambs, 122-133. In J. F. ROCHE, D. O'CALLAGHAN, Manipulation of growth in farm animals. Martinus Nijhoff. The Hague.

SPENCER G. S. G., 1985. Hormonal systems regulating growth. A review. Livest. Prod. Sci, 12. $31-46$.

SPENCER G. S. G., 1986. Immuno-neutralization of somatostatin and its effect on animal production. Dom. Anim. Endocr., 3, 55-68.

SPENCER G. S. G., GARSSEN G. J., BERGSTRÖM P. L., 1983. A novel approach to growth promotion using auto-immunization against somatostatin. Il. Effects of appetite, carcass composition and food utilization in lambs. Livest. Prod. Sci, 10, 469-477.

SPENCER G. S. G., HALLETT K. G., FADLALLA A. M., 1983. A novel approach to growth promotion using auto-immunisation against somatostatin. III. Effects in a commercial breed of sheep. Livest. Prod. Sci., 13, 43-52.

SPENCER G. S. G., GARSSEN G. J., HART I. C., 1983. A novel approach to growth promotion using auto-immunization against somatostatin. I. Effects on growth and hormone levels in lambs. Livest. Prod. Sci., 10, 25-37.

SPENCER G. S. G., GARSSEN G. J., WELLING A. M. A. W., 1985. Increased milk production by goats following immunization against somatostatin. Anim. Prod., 40, 572-573.

SPENCER G. S. G., HALLETT K. G., 1985. Somatostatin antagonist analogue stimulates growth in rats. Life Sci., 37, 27-30.

SPENCER G. S. G., HARVEY S., AUDSLEY A. R. S., HALLETT K. G., KESTIN S., 1986. The effect of immunization against somatostatin on growth rates and growth hormone secretion in the chicken. Comp. Biochem. Physiol., 85 A, 553-556.

SPENCER G. S. G., WILLIAMSON E. D., 1981. Increased growth in lambs following auto-immunization against somatostatin. Anim. Prod., 32, 376.

TYRRELL H. F., BROWN A. C. G., REYNOLDS P. J., HAALAND G. L., PEEL C. J., BAUMAN D. E., STEINHOUR W. D., 1982. Administration of bovine growth hormone to high yielding Holstein cows. I. Influence on in vivo energy metabolism. J. Dairy Sci., 65, Suppl. 1. 120.

VAN BUUL-OFFERS S., VAN DEN BRANDE J. L., 1979. Effects of growth hormone and peptide fractions containing somatomedin activity on growth and cartilage metabolism of Snell-dwarf mice. Acta endocr., 92, 242-257. 
VICINI J. L., CLARK J. H., HURLEY W. L., BAHR J. M., 1986. Effect of immunization against somatostatin on growth of young dairy calves. J. anim. Sci., 63, Suppl. 1, 242.

VON WERDER K., LOSA M., BOCK L., STALLA G. K., MULLER O. A., 1984. Growth hormone releasing factor infusion does not sustain elevated $\mathrm{GH}$ levels in normal subjects. Proc. 7th int. Congr. Endocrinol. Quebec. Excerpta med. int. Congr. Ser. No. 652 Amsterdam. Abstr. 2619.

WAGNER J. F., VEENHUIZEN E. L., 1978. Growth performance, carcass deposition and plasma hormone levels in wether lambs when treated with growth hormone and thyroprotein. $J$. anim. Sci., 47, Suppl. 1. 397.

WEHRENBERG W. B., BLOCH B., PHILLIPS B. J., 1984. Antibodies to growth hormone-releasing factor inhibit somatic growth. Endocrinology, 115, 1218-1220.

WEHRENBERG W. B., BRAZEAU P., LING N., TEXTOR G., GUILLEMIN R., 1984. Pituitary growth hormone response in rats during a 24-hour infusion of growth hormone-releasing factor. Endocrinologv, 114, 1613-1616.

WHEATLEY I. S., WALLACE A. L. C., BASSETT J. M., 1966. Metabolic effects of ovine growth hormone in sheep. J. Endocr., 35, 341-353.

WOLFRAM G. W., IVY R. E., BALDWIN C. D., 1985. Effects of exogenous growth hormone in growing beef cattle. J. anim. Sci., 61, Suppl. 1. Abstr. 104. 